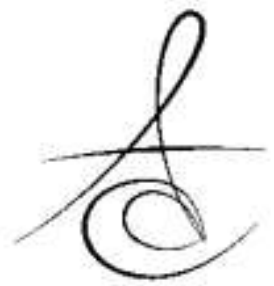

\title{
SODIUM THIOSULPHATE AND TWEEN 80 PREVENT THE FORMATION OF PARA- CHLOROANILINE IN THE IRRIGATING SOLUTIONS
}

\section{SODYUM TİYOSÜLFAT VE TWEEN 80 İRRİGASYON SOLÜSYONLARI İÇİNDE PARA-KLOROANİLİN FORMASYONUNU ENGELLER}

\author{
Dr. Öğr. Üyesi Ezgi DOĞANAY YILDIZ* \\ Uzm. Dt. Gizem TAŞ ${ }^{* * *}$ \\ Dr. Ali KESKİN*****
}

\author{
Doç. Dr. Hakan ARSLAN ${ }^{* *}$ \\ Arş. Gör. Dt. Eyüp Candaş GÜNDOĞDU**** \\ Dr. Alper YILDIRIM ${ }^{* * * *}$
}

\author{
Makale Kodu/Article code: 3960 \\ Makale Gönderilme tarihi: 18.01.2019 \\ Kabul Tarihi: 23.10.2019 \\ DOI : $10.17567 /$ ataunidfd.637010
}

Ezgi Doğanay Yıldız: ORCID ID: 0000-0003-4113-7794

Hakan Arslan: ORCID ID: 0000-0003-4890-1062

Gizem Taş: ORCID ID: 0000-0003-1525-5391

Eyüp Candaş Gündoğdu: ORCID ID: 0000-0002-4680-3912

Ali Keskin: ORCID ID: 0000-0003-3312-2576

Alper Yıldırım: ORCID ID: 0000-0003-1701-1606

\section{ABSTRACT}

Aim: The aim of the present study was to evaluate the effect of using sodium thiosulphate and Tween 80 to prevent the formation of para-chloroaniline (PCA) between $\mathrm{NaOCl}$ and $\mathrm{CHX}$ in the apically extruded irrigating solutions.

Materials and Methods: Twenty-five extracted human mandibular premolar teeth were instrumented up to size 40 . To collect the apically extruded irrigating solution, the roots were placed into the glass vial, and the specimens were divided into 5 groups according to the irrigation protocols, as follows; positive control, negative control, distilled water as intermediate flush between $\mathrm{NaOCl}$ and $\mathrm{CHX}$, sodium thiosulphate irrigation between $\mathrm{NaOCl}$ and $\mathrm{CHX}$, and Tween 80 irrigation between $\mathrm{CHX}$ and $\mathrm{NaOCl}$. The collected liquid was centrifuged and the precipitate was analyzed using $1 \mathrm{H}$ NMR spectra. The data were analyzed with chisquare test at $95 \%$ confidence level.

Results: PCA was detected for all specimens in the positive control group. PCA was absent in the negative control group. Although distilled water irrigation did not prevent the formation of PCA, sodium thiosulphate and Tween 80 prevented the formation of PCA between $\mathrm{NaOCl}-\mathrm{CHX}$ and $\mathrm{CHX}-\mathrm{NaOCl}$, respectively.

Conclusion: Within the limitations of the present study, sodium thiosulphate or Tween 80 prevented the formation of PCA between $\mathrm{NaOCl}-\mathrm{CHX}$ and $\mathrm{CHX}-\mathrm{NaOCl}$, respectively.

Keywords: chlorhexidine, para chloroaniline, sodium thiosulphate

Öz

Amaç: Bu çalışmanın amacı $\mathrm{NaOCl}$ ve $\mathrm{CHX}$ arasında sodyum tiyosülfat ve Tween 80 kullanımının apikalden ekstrüze olan irrigasyon solüsyonları içinde PCA formasyonunun önlenmesine etkisinin değerlendirilmesidir.

Gereç ve Yöntem: Yirmi-beş çekilmiş mandibular premolar diş 40 numaraya kadar genişletildi. Apikalden ekstrüze olan irrigasyon solüsyonlarının toplanması için, kökler cam şişe içine yerleştirildi, örnekler irrigasyon protokolüne göre 5 gruba ayrıldı: pozitif kontrol, negatif kontrol, $\mathrm{NaOCl}$ ve $\mathrm{CHX}$ arasında distile su ile yıkama, $\mathrm{NaOCl}$ ve $\mathrm{CHX}$ arasında sodyum tiyosülfat ile yıkama, $\mathrm{CHX}$ ve $\mathrm{NaOCl}$ arasında Tween 80 ile yıkama. Toplanan sIVı santrifüje edildi ve çökelti $1 \mathrm{H}$ NMR spectra ile analiz edildi. Veriler ki-kare testi ile \%95 güven aralığında analiz edildi.

Bulgular: Pozitif kontrol grubundaki tüm örneklerde PCA tespit edildi ve negatif gruptaki örneklerin hiçbirinde tespit edilmedi. Distile su irrigayonu PCA oluşumunu önlememesine rağmen, sodium tiyosülfat ve Tween 80 sırasıyla $\mathrm{NaOCl}-\mathrm{CHX}$ ve $\mathrm{CHX}-\mathrm{NaOCl}$ arasında kullanımla PCA formasyonunu engelledi.

Sonuç: Bu çalıșmanın limitasyonları dahilinde, sodium tiyosülfat ve Tween 80 , sırasıyla $\mathrm{NaOCl}-\mathrm{CHX}$ ve $\mathrm{CHX}-\mathrm{NaOCl}$ arasında kullanımla PCA formasyonunu engellemektedir.

Anahtar kelimeler: klorheksidin, para kloroanilin, sodyum tiyosülfat

${ }^{*}$ Department of Endodontics, Faculty of Dentistry, Kırıkkkale University, Kırıkkale, Turkey.

** Department of Endodontics, Faculty of Dentistry, Health Sciences University, İstanbul, Turkey.

*** Çorlu Oral and Dental Health Hospital, Tekirdağ, Turkey

**** Department of Oral and Maxillofacial Surgery, Faculty of Dentistry, Ataturk University, Erzurum, Turkey.

${ }^{* * * * *}$ Department of Chemistry, Faculty of Science, Ataturk University, Erzurum, Turkey.

Kaynakça Bilgisi: Ezgi Doğanay Yıldız E, Arslan P, Taş T, Gündoğdu EC, Keskın A, Yıldırım A. Solutions Sodyum Tiyosülftat ve Tween 80 İrrigasyon Solüsyonlari İçinde Para-Kloroanilin Formasyonunu Engeller. Atatürk Üniv Diş Hek Fak Derg 2020; 30: 61-65.

Citation Information: Ezgi Doganay Yildiz E, Arslan P, Tas T, Gundogdu EC, Keskin A, Yildirim A. Sodium Thiosulphate and Tween 80 Prevent The Formation of ParaChloroaniline In The Irrigating. J Dent Fac Atatürk Uni 2020; 30: 61-65. 
DOĞANAY YILDIZ, ARSLAN, TAŞ, GÜNDOĞDU, KESKİN, YILDIRIM

\section{INTRODUCTION}

One of the most important stages of the root canal treatment is the disinfection of the root canal system. ${ }^{1}$ However, solely chemomechanical preparation is not sufficient for the complete disinfection of the root canal system having complexities in its internal anatomy. ${ }^{2}$ Therefore, several antimicrobial irrigating solutions are used during preparation or as a final flush. Sodium hypochlorite $(\mathrm{NaOCl})$ is widely used in root canal treatment because of its capacity of dissolving organic tissue and antimicrobial properties. ${ }^{3-5}$ Despite of its advantages, $\mathrm{NaOCl}$ at high concentrations is toxic and it does not have antimicrobial substantivity. ${ }^{6,7}$ On the other hand, chlorhexidine ( $\mathrm{CHX})$ has a wide range of antimicrobial activity and its cationic structure provides antimicrobial substantivity. ${ }^{8}$ Therefore, the combined use of $\mathrm{NaOCl}$ and $\mathrm{CHX}$ has been suggested. ${ }^{9}$

Since Vivacqua-Gomes et al. $^{10}$ realized the formation of orange-brown precipitate resulting from the combined use of $\mathrm{CHX}$ and $\mathrm{NaOCl}$, a lot of studies have been conducted on the formation of precipitate, ${ }^{11}$ detection of para-chloroaniline (PCA) in the precipitate, ${ }^{12}$ and prevention of the precipitate or PCA formation. ${ }^{13,14}$ Bui et al. ${ }^{11}$ evaluated the formation of precipitate on root dentin and dentinal tubules by using the environmental scanning electron microscope and found that the combination of $\mathrm{NaOCl}$ and $\mathrm{CHX}$ resulted in formation of precipitate tending to occlude the dentinal tubules. The PCA in the precipitate was first reported by Basrani et al. ${ }^{12}$ The PCA was then detected in other studies by using gas chromatographymass spectrometry, ${ }^{13}, 15$ time-of-flight secondary ion mass spectrometry ${ }^{16}$ or nuclear magnetic resonance (NMR) spectroscopy. ${ }^{17}$ PCA in humans is a potent cyanogenic, carcinogenic, ${ }^{18}$ toxic agent, and has immunotoxic effects. ${ }^{19}$ As for precautions to prevent the formation of PCA, several irrigating solutions were used between $\mathrm{NaOCl}$ and $\mathrm{CHX}$. Distilled water, ${ }^{14}$ saline, ${ }^{13,14}$ isopropyl alcohol, ${ }^{14}$ EDTA, ${ }^{13}$ citric acid ${ }^{13}$ were found to be insufficient to prevent PCA.

In previous reports sodium thiosulphate ${ }^{20-22}$ and Tween $80^{21,23}$ have been extensively used to inhibit the antibacterial effects of $\mathrm{NaOCl}$ and $\mathrm{CHX}$, respectively. However, there is no study in the literature evaluating the effect of using sodium thiosulphate and Tween 80 between $\mathrm{NaOCl}$ and $\mathrm{CHX}$ to prevent the formation of PCA. Thus, the aim of the present study was to evaluate the effect of using sodium thiosulphate and Tween 80 between $\mathrm{NaOCl}$ and $\mathrm{CHX}$ to prevent the formation of PCA in the apically extruded irrigating solutions. The null hypothesis was that there would be no differences between the groups.

\section{MATERIALS AND METHODS}

Twenty-five extracted human mandibular premolar teeth with similar dimensions were selected according to the following inclusion criteria: noncarious, fully formed apex, single root, single root canal, intact root without cracks or fractures, and a root canal curvature of $<10^{\circ}$. The extraction reasons of the teeth were not related to this study. The exclusion criteria were as following: previously root canal filled, internal/external resorption, and root canal calcification. To obtain a standardized length of $14 \mathrm{~mm}$, the teeth were decoronated using a diamond disc.

A \#10 K-file (Dentsply/Maillefer, Ballaigues, Switzerland) was inserted into the root canal. The length, at which the tip of file was visible at the apical foramen, was recorded and the working length was set as $1 \mathrm{~mm}$ less than this length. Root canal preparation was achieved with ProTaper Universal rotary instruments (Dentsply/Maillefer, Ballaigues, Switzerland) up to size $40.2 \mathrm{~mL}$ of $5 \% \mathrm{NaOCl}$ was used between each instrument change. To collect the apically extruded irrigating solution, the root was placed into the glass vial after silicone impression material was placed. The samples were randomly divided into 5 groups, according to the irrigation procedure, as follows:

Positive control: $5 \mathrm{~mL}$ of $5 \% \mathrm{NaOCl}$ followed by $5 \mathrm{~mL}$ of $2 \% \mathrm{CHX}$,

Negative control: $5 \mathrm{~mL}$ of distilled water,

Distilled water: $5 \mathrm{~mL}$ of distilled water irrigation between $5 \% \mathrm{NaOCl}$ and $2 \% \mathrm{CHX}$,

Sodium thiosulphate: $5 \mathrm{~mL}$ of $5 \%$ sodium thiosulphate (Meck, Darmstadt, Germany) irrigation between $5 \% \mathrm{NaOCl}$ and $2 \% \mathrm{CHX}$,

Tween 80: $5 \mathrm{~mL}$ of $3 \%$ Tween 80 (Meck, Darmstadt, Germany) irrigation between 2\% CHX and $5 \% \mathrm{NaOCl}$.

30 gauge side port endodontic needle with 25 $\mathrm{mm}$ length (Canal Clean, Biodent, Paju City, South Korea) was used for all irrigation procedures. The canals were then dried with paper points. The roots and silicone impression material were removed from the glass vials. The collected liquid was transferred to the microfuge tubes. The microfuge tubes were 
DOĞANAY YILDIZ, ARSLAN, TAŞ, GÜNDOĞDU, KESKİN, YILDIRIM

centrifuged for $10 \mathrm{~min}$ at $7500 \mathrm{rpm}$ and the photographs of the tubes were taken (Fig 1). The precipitate solids were removed, dissolved in d6-DMSO or $\mathrm{CD}_{3} \mathrm{OD}$ solvents and analyzed using ${ }^{1} \mathrm{H}$ NMR spectra. The data were recorded as the presence or absence of the PCA and analyzed with chi-square test at the $95 \%$ confidence level $(P=.05)$.

\section{RESULTS}

PCA was detected for all specimens in the positive control (Figure $1 \mathrm{~A}$ and Figure $2 \mathrm{~A}$ ) and no PCA was formed in the negative control group (Figure $1 B$ and Figure $3 \mathrm{~A}$ ). Distilled water irrigation between $\mathrm{NaOCl}$ and $\mathrm{CHX}$ did not prevent the formation of PCA (Figure $1 \mathrm{C}$ and Figure 2B). Sodium thiosulphate (Figure 2D and Figure 3B) and Tween 80 (Figure $1 \mathrm{E}$ and Figure $3 \mathrm{C}$ ) prevented the formation of $\mathrm{PCA}$ between $\mathrm{NaOCl}-\mathrm{CHX}$ and $\mathrm{CHX}-\mathrm{NaOCl}$, respectively ( $P$ $<.001$ ) (Table 1).

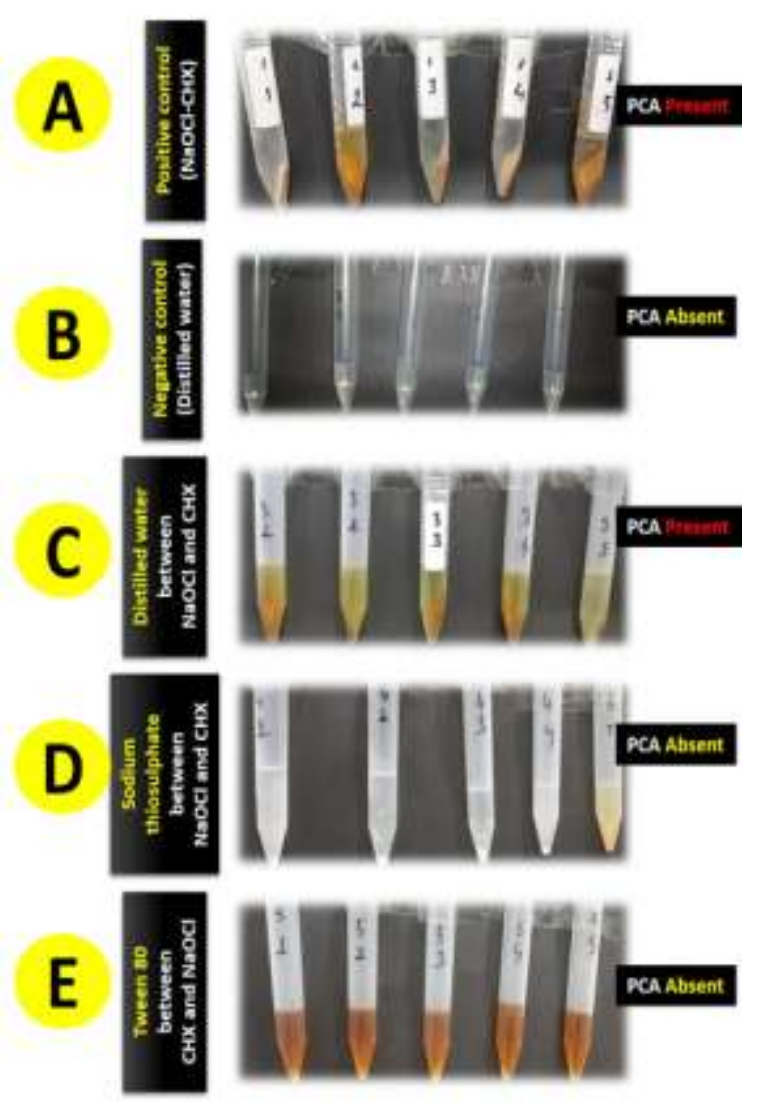

Figure 1. Images after centrifuge.
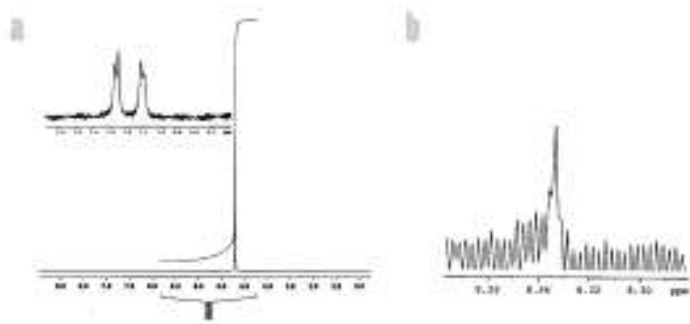

Figure 2. A peak between 7 and $8 \mathrm{ppm}$ demonstrated the presence of para-chloroaniline. All of the spectra were obtained with a $400-\mathrm{MHz}$ Bruker NMR System at $25^{\circ} \mathrm{C}$, acquiring 32 scans, in d6-DMSO solvent. Representative images for a) positive control ( $\mathrm{NaOCl}-\mathrm{CHX})$ and b) distilled water between $\mathrm{NaOCl}$ and $\mathrm{CHX}$.

Table 1. The number of specimens with PCA formation according to the groups. There were statistically significant differences among the groups $(P<.001)$.

\begin{tabular}{|c|c|c|}
\hline \multirow[t]{2}{*}{ Groups } & \multicolumn{2}{|c|}{$\begin{array}{c}\text { Para- } \\
\text { Chloroaniline }\end{array}$} \\
\hline & Absent & Present \\
\hline Positive control ( $\mathrm{NaOCl}-\mathrm{CHX})$ & 0 & 5 \\
\hline Negative control (Distilled water) & 5 & 0 \\
\hline Distilled water between $\mathrm{NaOCl}$ and $\mathrm{CHX}$ & 0 & 5 \\
\hline Sodium Thiosulphate between $\mathrm{NaOCl}$ and $\mathrm{CHX}$ & 5 & 0 \\
\hline Tween 80 between $\mathrm{CHX}$ and $\mathrm{NaOCl}$ & 5 & 0 \\
\hline
\end{tabular}

\section{DISCUSSION}

Since the combined use of $\mathrm{NaOCl}$ and $\mathrm{CHX}$ has been suggested ${ }^{8,} 9$ there are several arguments related to the prevention of PCA. ${ }^{13,}{ }^{14}$ However, no tested irrigation solutions prevent the formation of PCA. ${ }^{13,}{ }^{14}$ In the literature, there are a lot of studies using sodium thiosulphate ${ }^{20-22}$ or Tween $80^{21,23}$ to inhibit the effects of $\mathrm{NaOCl}$ and $\mathrm{CHX}$, respectively. However, there is no study in the literature evaluating the effect of using sodium thiosulphate and Tween 80 between $\mathrm{NaOCl}$ and $\mathrm{CHX}$ to prevent the formation of PCA. Thus, the aim of the present study was to evaluate the effect of using sodium thiosulphate and Tween 80 between $\mathrm{NaOCl}$ and $\mathrm{CHX}$ to prevent the formation of PCA in the apically extruded irrigating solutions. According to the findings of the present study, there were statistically significant differences among the groups $(P<.001)$. Thus, the null hypothesis was rejected.

Mortenson et al. ${ }^{13}$ tested sterile saline, citric acid and EDTA to prevent the formation of PCA on root canals and found that although citric acid has the least amount of PCA formation in the canal system, none of the tested irrigating solutions prevented the formation of PCA in the canal system. Krishnamurthy

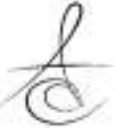


DOĞANAY YILDIZ, ARSLAN, TAŞ, GÜNDOĞDU, KESKİN, YILDIRIM

and Sudhakaran ${ }^{24}$ evaluated the effectiveness of absolute alcohol, saline and distilled water to remove residual $\mathrm{NaOCl}$ and thereby prevent the formation of the precipitate, and found that PCA formation can be prevented using absolute alcohol and minimized using saline and distilled water as intermediate flushes. Krishnamurthy and Sudhakaran ${ }^{24}$ also concluded that further investigation of the $\mathrm{NaOCl} / \mathrm{CHX}$ precipitate in endodontic situations should address the bioavailability of PCA leaching out of the canal. In this sense, the present study evaluated the PCA formation in apically extruded irrigating solutions and revealed that distilled water was insufficient to prevent PCA formation in apically extruded irrigating solutions. However, sodium thiosulphate after $\mathrm{NaOCl}$ and Tween 80 after $\mathrm{CHX}$ prevent the formation of PCA. These results can be attributed to the inhibition effect of sodium thiosulphate on $\mathrm{NaOCl}^{20-22}$ and the inhibition effect of Tween 80 on $\mathrm{CHX}$. ${ }^{21,} 23$

PCA occludes the dentinal tubules and may compromise the seal of the obturated canal. PCA is cytotoxic, leading to the concern of it leaching out of the canal, and hence it has to be prevented or removed. ${ }^{11,15}$ Metri et al. ${ }^{25}$ evaluated the effect of Ffile and passive ultrasonic irrigation on removal of PCA and concluded that both of the techniques failed to completely remove PCA. Guneser et al. ${ }^{26}$ compared different irrigation activation methods (conventional syringe, endodontic microbrush, sonic activation, photon-induced photoacustic streaming) in terms of removal of PCA and concluded that none of the techniques completely removed PCA from the root canals. Since it is difficult to remove PCA, it is very important to prevent it from occurring.

$1 \mathrm{H}-\mathrm{NMR}$ spectrum has been used in previous studies evaluating the formation of PCA. ${ }^{17,27}$ In the present study, apically extruded irrigating solutions was collected, centrifuged and then analyzed by using $1 \mathrm{H}-\mathrm{NMR}$ spectrum. 1H-NMR spectrum exposes the specimens to a magnetic field and then to radiofrequencies that act on atomic nuclei. ${ }^{27}$ Some authors found that $\mathrm{NaOCl}$ and $\mathrm{CHX}$ did not produce free PCA in any measurable quantity. ${ }^{27,}{ }^{28}$ However, in other studies the PCA was determined in the mixture of $\mathrm{NaOCl}$ and $\mathrm{CHX} .{ }^{11-13,15-17}$ In the present study, PCA formation was determined in mixture of $\mathrm{NaOCl}$ and $\mathrm{CHX}$ collected from apically extruded irrigating solutions.

The present study revealed that sodium thiosulphate and Tween 80 can be beneficial as intermediate flush to prevent PCA formation. However, further studies should be conducted to confirm the findings of the present study.

\section{CONCLUSION}

Sodium thiosulphate inactivates $\mathrm{NaOCl}$ and Tween 80 inactivates $\mathrm{CHX}$ in apically extruded irrigating solutions. Within the limitation of the present study, sodium thiosulphate and Tween 80 prevents the formation of PCA between $\mathrm{NaOCl}-\mathrm{CHX}$ and $\mathrm{CHX}$ $\mathrm{NaOCl}$, respectively.

NOT: Çalışmada herhangi bir yazar, kurum ya da kuruluş ile çıkar çatışması içerisinde bulunmamaktadır. Makale daha önce hiçbir yerde yayınlanmamış ve yayınlanmak üzere işlem görmemektedir

\section{REFERENCES}

1. Bystrom A, Claesson R, Sundqvist $G$. The antibacterial effect of camphorated paramonochlorophenol, camphorated phenol and calcium hydroxide in the treatment of infected root canals. Endod Dental Traumatol 1985;1:170-5.

2. Bystrom A, Sundqvist G. Bacteriologic evaluation of the efficacy of mechanical root canal instrumentation in endodontic therapy. Scand J Dent Res 1981;89:321-8.

3. Zehnder M. Root canal irrigants. J Endod 2006;32:389-98.

4. Gutierrez JH, Jofre A, Villena F. Scanning electron microscope study on the action of endodontic irrigants on bacteria invading the dentinal tubules. Oral Surg Oral Med Oral Pathol 1990;69:491-501.

5. Mutluay AT, Mutluay M . Sodyum hipoklorit : endodontide kullanım alanları . J Dent Fac Atatürk Uni. 2015;25:258-65.

6. Holland R, Soares IJ, Soares IM. Influence of irrigation and intracanal dressing on the healing process of dogs' teeth with apical periodontitis. Endod Dent Traumatol 1992;8:223-9.

7. White RR, Hays GL, Janer LR. Residual antimicrobial activity after canal irrigation with chlorhexidine. J Endod 1997;23:229-31.

8. Mohammadi Z, Abbott PV. The properties and applications of chlorhexidine in endodontics. Int Endod J 2009;42:288-302.

9. Kuruvilla JR, Kamath MP. Antimicrobial activity of $2.5 \%$ sodium hypochlorite and $0.2 \%$ chlorhexidine gluconate separately and combined, as endodontic irrigants. J Endod 1998;24:472-6.

10. Vivacqua-Gomes N, Ferraz CC, Gomes BP, Zaia AA, Teixeira FB, Souza-Filho FJ. Influence of irrigants 
DOĞANAY YILDIZ, ARSLAN, TAŞ, GÜNDOĞDU, KESKİN, YILDIRIM

on the coronal microleakage of laterally condensed gutta-percha root fillings. Int Endod J 2002;35:791-5.

11. Bui TB, Baumgartner JC, Mitchell JC. Evaluation of the interaction between sodium hypochlorite and chlorhexidine gluconate and its effect on root dentin. J Endod 2008;34:181-5.

12. Basrani BR, Manek S, Sodhi RN, Fillery E, Manzur A. Interaction between sodium hypochlorite and chlorhexidine gluconate. J Endod 2007;33:966-9.

13. Mortenson D, Sadilek M, Flake NM, Paranjpe A, Heling I, Johnson JD, et al. The effect of using an alternative irrigant between sodium hypochlorite and chlorhexidine to prevent the formation of para-chloroaniline within the root canal system. Int Endod J 2012;45:878-82.

14. Magro MG, Kuga MC, Aranda-Garcia AJ, Victorino $\mathrm{KR}$, Chávez-Andrade GM, Faria $\mathrm{G}$, et al. Effectiveness of several solutions to prevent the formation of precipitate due to the interaction between sodium hypochlorite and chlorhexidine and its effect on bond strength of an epoxy-based sealer. Int Endod J 2015;48:478-83.

15. Basrani BR, Manek S, Mathers D, Fillery E, Sodhi RN. Determination of 4-chloroaniline and its derivatives formed in the interaction of sodium hypochlorite and chlorhexidine by using gas chromatography. J Endod 2010;36:312-4.

16. Kolosowski KP, Sodhi RN, Kishen A, Basrani BR. Qualitative analysis of precipitate formation on the surface and in the tubules of dentin irrigated with sodium hypochlorite and a final rinse of chlorhexidine or QMiX. J Endod 2014;40:2036-40.

17. Arslan H, Uygun AD, Keskin A, Karatas E, Seckin F, Yildirim A. Evaluation of orange-brown precipitate formed in root canals after irrigation with chlorhexidine and QMix and spectroscopic analysis of precipitates produced by a mixture of chlorhexidine/ $\mathrm{NaOCl}$ and $\mathrm{QMix} / \mathrm{NaOCl}$. Int Endod J 2015;48:1199-203.

18. Chhabra RS, Huff JE, Haseman JK, Elwell MR, Peters AC. Carcinogenicity of p-chloroaniline in rats and mice. Food Chem Toxicol 1991;29:119-24.

19. Kacmar P, Pistl J, Mikula I. The effect of pchloroaniline on leucocytes of sheep peripheral blood under the migration-inhibition test conditions. Immunopharmacol Immunotoxicol 1995; 17:577-84.

20. Radcliffe CE, Potouridou L, Qureshi R, Habahbeh $\mathrm{N}$, Qualtrough A, Worthington $\mathrm{H}$, et al.
Antimicrobial activity of varying concentrations of sodium hypochlorite on the endodontic microorganisms Actinomyces israelii, A. naeslundii, Candida albicans and Enterococcus faecalis. Int Endod J 2004;37:438-46.

21. Guerreiro-Tanomaru JM, Morgental RD, FariaJunior NB, Berbert FLCV, Tanomaru-filho $M$. Antibacterial effectiveness of peracetic acid and conventional endodontic irrigants. Braz Dent J 2011;22:285-87.

22. Moghadas L, Shahmoradi M, Narimani T. Antimicrobial activity of a new nanobased endodontic irrigation solution: In vitro study. Dental Hypotheses 2012;3:142.

23. Tirali RE, Bodur $H$, Ece $G$. In vitro antimicrobial activity of sodium hypochlorite, chlorhexidine gluconate and octenidine dihydrochloride in elimination of microorganisms within dentinal tubules of primary and permanent teeth. Med Oral Patol Oral Cir Bucal 2012;17:e517-22.

24. Krishnamurthy S, Sudhakaran S. Evaluation and prevention of the precipitate formed on interaction between sodium hypochlorite and chlorhexidine. J Endod 2010;36:1154-7.

25. Metri M, Hegde S, Dinesh K, Indiresha HN, Nagaraj S, Bhandi SH. Comparative Evaluation of Two Final Irrigation Techniques for the Removal of Precipitate Formed by the Interaction between Sodium Hypochlorite and Chlorhexidine. J Contemp Dent Pract 2015;16:850-3.

26. Guneser MB, Dincer AN, Arslan D. Comparison of Conventional Syringe, CanalBrush, EndoActivator, Photon-Induced Photoacoustic Streaming, and Manual Instrumentation in Removing OrangeBrown Precipitate: An In Vitro Study. Photomed Laser Surg 2017;35:311-16.

27. Thomas JE, Sem DS. An in vitro spectroscopic analysis to determine whether para-chloroaniline is produced from mixing sodium hypochlorite and chlorhexidine. J Endod 2010;36:315-7.

28. Orhan EO, Irmak O, Hur D, Yaman BC, Karabucak B. Does Para-chloroaniline Really Form after Mixing Sodium Hypochlorite and Chlorhexidine? J Endod 2016;42:455-9.

\section{Yazışma Adresi}

Ezgi DOGANAY YILDIZ

Department of Endodontics, Faculty of Dentistry, Kırıkkale University,

Kırıkkale, 71450, TURKEY

Telephone number: +90.318.224 4927- 7366

E-mail address: dtezgidoganay@gmail.com 